\title{
The Impact of Foreign Direct Investment on Economic Growth in Libya
}

\author{
Mustafa El. Hamoudi, Nagmi Aimer
}

\begin{abstract}
The study examined the impact of FDI on economic growth in Libya, the study relied on statistical analysis techniques for SPSS, after analyzing the data using several techniques for statistical analysis or revealing the relationship between independent variables (foreign investment, labor force, the inflation rate in the economy) And the dependent variable (growth rate in the Libyan economy) for 16 years during the period 20002015. In the light of data analysis, a quantitative approach was used using self-regression analysis. The results of the normative analysis of the relationship between growth rate In Libya and some independent variables, the increase in foreign direct investment by $1 \%$ leads to an increase in GDP by $0.215 \%$, the estimated public line gave the best results, and this satisfies the assumption that increasing foreign direct investment leads to a high rate of economic growth in Libya.
\end{abstract}

Keywords- Foreign Direct Investments, growth economic, Gross domestic product, The Libyan economy.

\section{INTRODUCTION}

Foreign direct investment (FDI) is one of the most important and widely traded economic issues in recent years, as developing countries are particularly eager to attract foreign direct investment. Foreign direct investment (FDI) is the movement of foreign capital to invest directly abroad, which is one of the main drivers of economic growth in the country. In many ways, foreign direct investment contributes to expanding the investment base in the country, as well as solving the problem of unemployment by creating new jobs, introducing the advanced technology of the state, and identifying modern methods of management, organization, communication, and marketing, top and greater experience.States are generally aware of the importance of foreign direct investment, so they always seek to attract foreign investment to them by creating the appropriate climate that stimulates foreign investment, providing facilities and incentives to foreign investors.The issue of foreign direct investment is, therefore, receiving considerable attention from decision makers around the world. FDI is an important source of financing, especially in developing countries, including Arab countries, where foreign direct investment plays an important role in driving economic growth in these countries.It is expected that the Libyan economy cannot attract foreign investors or Libyans preferred to run their business outside Libya. The lack of public services such as electricity and water and the difficulty of moving between Libyan cities due to the security situation between some of the Libyan cities, whether those of the former regime or the February revolution.Investments are in need of an environment of services, security and stability at the level of political, administrative and legislative institutions, all of which are almost according to the Libyan state or international institutions that are not available. There are also legislative obstacles at the level of legal facilities sought by investors such as low tax rates and customs facilities, The complex bureaucracy within state institutions that forces investors either to aversion or to knock the doors of corruption.

\section{PROBLEM OF THE STUDY}

Libya focuses on foreign direct investment to stimulate economic growth and revive the Libyan economy. It has always sought to attract foreign investors by providing incentives and facilities that stimulate foreign investors to invest in Libya. Foreign direct investment (FDI) in Libya between 2000 and 2010 increased significantly, with total foreign direct investment in 2000 totaling \$ 141 million, while total FDI in 2010 was $\$ 1.784$ billion. But after 2011 after the popular uprising, the volume of foreign investment shrank to \$50 million in 2014 .

Accordingly, the problem of the study can be summarized in the following question:

What is the impact of FDI on Libya's economic growth?

\section{Study Hypothesis:}

The hypothesis of the study is as follows:

"The increase in foreign direct investment leads to a high rate of economic growth in Libya".

\section{Purpose of the study}

The study contributes to highlighting the importance of foreign investment in terms of its concept, forms and importance in the economy, and clarifying why Libya is always seeking to attract foreign investment to it. The study also aims at measuring the impact of foreign investments on economic growth in Libya by building a standard model that helps analyze this relationship. The study also seeks to guide policymakers and decisionmakers to the important role of FDI and its impact on economic growth. 


\section{The importance of studying:}

The current study differs from previous studies in several places. This study deals with the application of the relationship in Libya, while the previous studies dealt with different countries. In addition to applying a standard model, while most of the previous studies focused on the theoretical side. The present study is characterized by a modernity of the period of time used.

Scope of study:

This study is applied in Libya due to the lack of studies that dealt with this aspect during the period (2000-2015) according to the availability of data.

\section{Methodology of the study:}

The methodology of the study is based on the descriptive method of describing the phenomenon by explaining the concepts, forms and determinants of foreign investment. The study also relies on the standard method of determining the role of foreign investments in economic growth in Libya by building a standard model through the SPSS program.

\section{Previous studies:}

The study of foreign investments has received some research and investigation at both the global and local levels because of its effective impact on the economies of their host countries. The most prominent of these studies, which examined the study of FDI, will be reviewed in various aspects.

Several studies have examined the impact of foreign direct investment on economic growth in a descriptive and standard manner. Although these studies differed in terms of spatial and temporal application and standard methods used, most agreed on a direct relationship between FDI and economic growth. The most important of these studies (Muhammad al-Minafi, Lihwa Yang, 2015), Mustafa al-Hammoudi (2016), Abd al-Hakim Abushwa, Tariq Zarrouq, 2016, Bandar al-Zahrani (2004) These studies were based primarily on the criteria of the new classical growth theory created by Solo and Swan (Rogers, 2003) According to the new classical growth framework, the impact of FDI On long-term economic growth through increased production, increased capital formation, population growth and technological progress (Rogers, 2003). Foreign direct investment and its relationship to long-term economic growth in the host country, including improved per capita GDP growth, improved domestic investment, transfer of new technologies to the host country, human capital development, capital increase, accumulation and increase of exports. That the benefits of foreign direct investment depend primarily on the business environment of the host country, which includes determinants of foreign direct investment and economic strategies and policies that would increase FDI flows to host economies (OECD)
OECD, 2000). The hypothesis of this thought is confirmed and supported by empirical studies (Burnstein et al., 1998, Asdov, 2007). On the one hand, it should be noted that foreign direct investment companies and investors are looking to achieve their interests in the host country, including access to full profitability and reduced costs.

According to the National Oil Corporation's database, most of the foreign investors investing in Libya's oil production sector come from the United States and European countries. Similarly, the largest buyers of oil are the United States and European countries, review literature for this study have two goals. First, the report aims to provide brief sets of literature on the overall role of FDI in economic growth in host countries. Secondly, it attempts to provide an overview of the effects of foreign direct investment on export growth and economic growth in host countries.

The theoretical framework of foreign direct investment and its relation to economic growth

This topic will explain the concept, importance and forms of foreign direct investment, and its main determinants and impact on the growth of economic thought.

\section{The concept of foreign direct investment}

There are many concepts of foreign direct investment, defined asThere are many concepts of foreign direct investment, defined as is an Investing in assets or items that are purchased in the hope that it will generate income in the future.(Mustafa El. Hamoudi, 2017, VOLUME 6, ISSUE 02).

"those investments run by foreigners because of their full ownership or ownership of a share that justifies the right of management, and most of these investments are carried out by multinational companies".

The Foreign direct investment it ${ }^{\text {ee }} \mathrm{s}$ as a conception doesn'teet go out of ,it is an addition to the product energy or an addition to capital.(Mustafa El. Hamoudi 2016, (ISSN) Vol- 4, Issue 2).

The report of the United Nations Conference on Trade and Development (FDI) defines FDI as "a type of investment involving a long-term relationship that reflects permanent interests and the ability to manage the company in the parent country and the company in another country, With the parent company's participation rate exceeding 50\%".

The World Trade Organization and the Organization for Economic Cooperation and Development defined foreign direct investment as "any stable investment activity in a particular country (country of origin), which has assets in another country (the host country), In order to manage these investments.

Importance of Foreign Direct Investment: 
Foreign direct investment (FDI) is of great importance to the economies of host countries, as it has many positive effects, contributing to higher investment rates through FDI flows. It also plays an important role in creating new jobs and thus reducing unemployment, which is a widespread phenomenon in developing countries. Foreign direct investment also affects the balance of payments through the inflow of foreign capital, making it a good source of foreign currency access and the increase of physical capital in host countries.

Foreign direct investment (FDI) contributes to the transfer of advanced technology and modern management skills to host countries, which have a major role in developing the skills of workers and raising the efficiency of production due to the experience of foreign companies in economic activity and their extensive knowledge of the arts of production and marketing. FDI also contributes to the development of the export sector, which is an urgent need in developing countries. It increases the interest in R \& D in the host countries. It also contributes to increasing productivity and production, thus increasing national income and thus increasing average per capita income.

However, despite the positive effects of foreign direct investment, it has negative effects on host countries. FDI is a means of depleting the wealth of developing countries and foreign investors may bring technology that is not commensurate with the conditions of developing countries that are predominantly unemployed, The existence of this type of technology, which relies on the heavy use of capital, exacerbates the problem of unemployment. Foreign direct investment may increase the monopoly of domestic markets in host countries, thereby increasing the dependence of developing countries on developed countries.

\section{Forms of FDI:}

Foreign direct investment takes many forms depending on the nature of ownership of productive assets in host countries, including joint investment, wholly owned investment, as well as investment in collections or aggregations, as well as free zones. These forms will be discussed in detail.

\section{Joint Investment:}

Joint investment or, as it is sometimes called bilateral foreign investment, is defined as "a business enterprise owned or shared by two or more of two permanently different States."

Where the partnership is in capital, trademarks, management, patent and others. This type of FDI is therefore accepted and supported by host States, in particular developing countries, because it provides them with the advantages of foreign direct investment without giving up their right to control projects on their territory at the same time. Joint investment reduces the degree of control by foreign investors and helps to strengthen national ownership.

\section{Fully owned investment:}

This form of foreign direct investment is more favored by the foreign investor, because the foreign investor has full freedom of management and marketing, and has the right to establish branches of production and marketing elsewhere. Most developing countries are hesitant to turn to foreign direct investment for fear of economic dependence by controlling foreign markets and leading to monopoly.

Investing in collections or aggregations:

These projects take the form of an agreement between the foreign party and the local party, where the foreign party supplies the local party with components of a particular product to be assembled to become a finished product. In some cases, especially in developing countries, the foreign party provides the necessary expertise and knowledge related to the internal design of the plant Storage and maintenance methods and capital equipment in exchange for an agreed return, while the local party collects the product in this country.

\section{Free Zones:}

The free zone means "that area which lies within the geographical boundaries of the State but is outside the customs regime of that State, allowing for the entry of imports and exports without customs duties". The free zones offer many facilities and incentives to the foreign investor by exempting foreign companies from income tax, not imposing customs duties on imported resources, and facilitating the establishment of workers and the provision of energy in these areas at subsidized prices.

\section{FDI determinants:}

Economic determinants are the most important determinants of FDI decision makers. These determinants are market size, political and economic stability, infrastructure, a legislative and regulatory framework, a judicial system, and financial incentives for foreign investors. (Demerhan, E, \& Masaka, M. (2008).

Market size is one of the most important determinants of a foreign investor's decision. The larger the market, the greater the flow of foreign investment. Political and economic stability are essential elements in attracting foreign direct investment. A stable and secure environment is an attractive factor for foreign direct investment because foreign investors do not accept risking their capital in an unstable environment that could lead to a loss.

Infrastructure, such as roads, means of transportation, airports and electricity networks, also contributes to attracting foreign direct investment (FDI) to host countries. A good infrastructure contributes to reducing 
costs and thereby increasing investor profits. Countries with weak infrastructure may have difficulties in attracting large volumes of FDI.

The existence of a legislative and regulatory framework that governs FDI activities is an important driver of investment, as a uniform and transparent investment law helps

to attract investment. The existence of adequate safeguards that protect foreign investors from the risks that they may face in host countries such as nationalization and others is an important factor that plays a major role in influencing the investor's decision.

As well as an independent judicial system with the capacity to implement laws and contracts, capable of resolving disputes that may arise between foreign investors and host countries with high efficiency and impartial integrity, are factors influencing the decision of the foreign investor. The provision of fiscal incentives, such as tax incentives for capital goods imported from customs duties, as well as financing incentives such as direct government subsidies, contributes to attracting foreign direct investment.

\section{Impact of Foreign Direct Investment on Growth in Economic Thought:}

The feasibility of foreign investment is an important focus, and the following is the view of both classical thought and neo-classical thought in this regard.

\section{Classical thought:}

Foreign direct investment (FDI) is a means of channeling savings to investment in host developing countries in accordance with classical thinking, and the technological advances of FDI play an important role in influencing the rate of economic growth. Despite the many advantages that FDI brings, there is a difference in the views of the classics in terms of their impact on the rate of economic growth. Where some believe that foreign direct investment has a positive impact on economic growth if the host country provides the appropriate investment environment and the necessary elements to attract it.

\section{Neoclassical thought:}

The neo-classical thought holds that technological progress has a positive impact on the rate of economic growth. As the increase in foreign direct investment inflows leads to an increase in the associated technology, thereby increasing economic growth. Neoclassical thought with classical thought agreed on the importance of FDI in injecting savings into investment in developing host countries. And that foreign direct investment leads to an increase in capital flows, driving economic growth. The more FDI flows, the more capital flows and thus the rate of economic growth increases.

\section{The reality of FDI in Libya.}

Most countries in the world seek to generate high rates of economic growth by pursuing different policies that lead to this goal. Libya focused on attracting foreign direct investment to move its economy and diversify its production base. Foreign direct investment has received considerable attention from the Government.

It was the increased attention to foreign direct investment, of its crucial role in economic development, Libya is one of these countries, which focused on improving the foreign investment climate.(Mustafa El. Hamoudi,2016, Open Access Library Journal, Volume 3, e3184 ISSN Online).

This topic will address the importance of attracting foreign direct investment to Libya. It will also discuss the investment climate in Libya and the development of foreign direct investment in Libya.

Importance of attracting foreign direct investment to Libya:

Libya seeks to attract foreign direct investment to transfer and settle modern technology to the country, realizing that economic growth has become closely linked to modern technology and knowledge progress in the country.

Libya is also aware of the importance of attracting foreign direct investment in diversifying its production base and increasing its GDP. Increasing the flow of foreign direct investment in Libya will lead to an increase in GDP and thus improve the welfare of the Libyan people. The figure below shows the relationship of foreign direct investment to GDP in Libya during the period 2000-2015. 


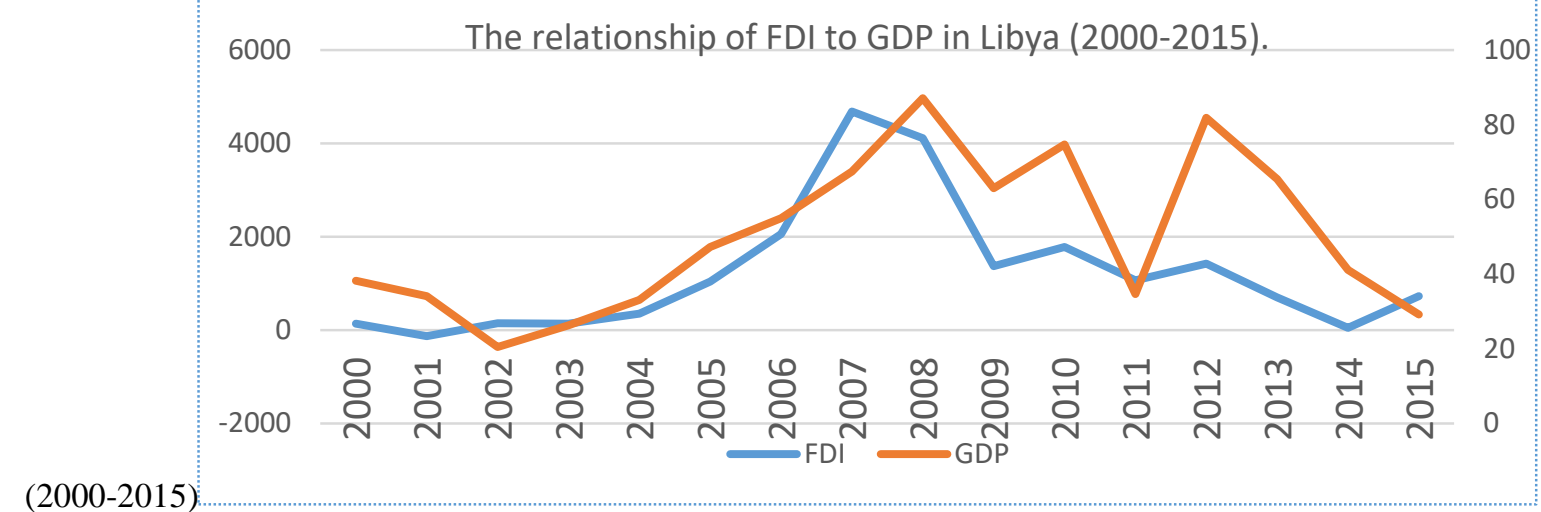

Fig.1: The relationship of foreign direct investment to GDP in Libya during the period

Source: prepared by researchers, depending on: - UNCTAD, online statistics database.

As shown in the previous figure, FDI in Libya is positively correlated with GDP, as the rise in foreign direct investment (2000-2015) has led to GDP growth.

The increase in the flow of foreign direct investment during the period indicated that Libya was able to maintain its attractiveness, continued to provide distinctive services that are a major attraction in the inflow of investments and inject more capital into major projects, led to its rise.
Libya also seeks foreign direct investment to contribute to the reduction of unemployment. The presence of multinational companies helps to increase employment opportunities and plays a major role in the rehabilitation and development of national manpower, which makes them able to compete in the local and international markets. The figure below shows the correlation between FDI development and the labor force in Libya.

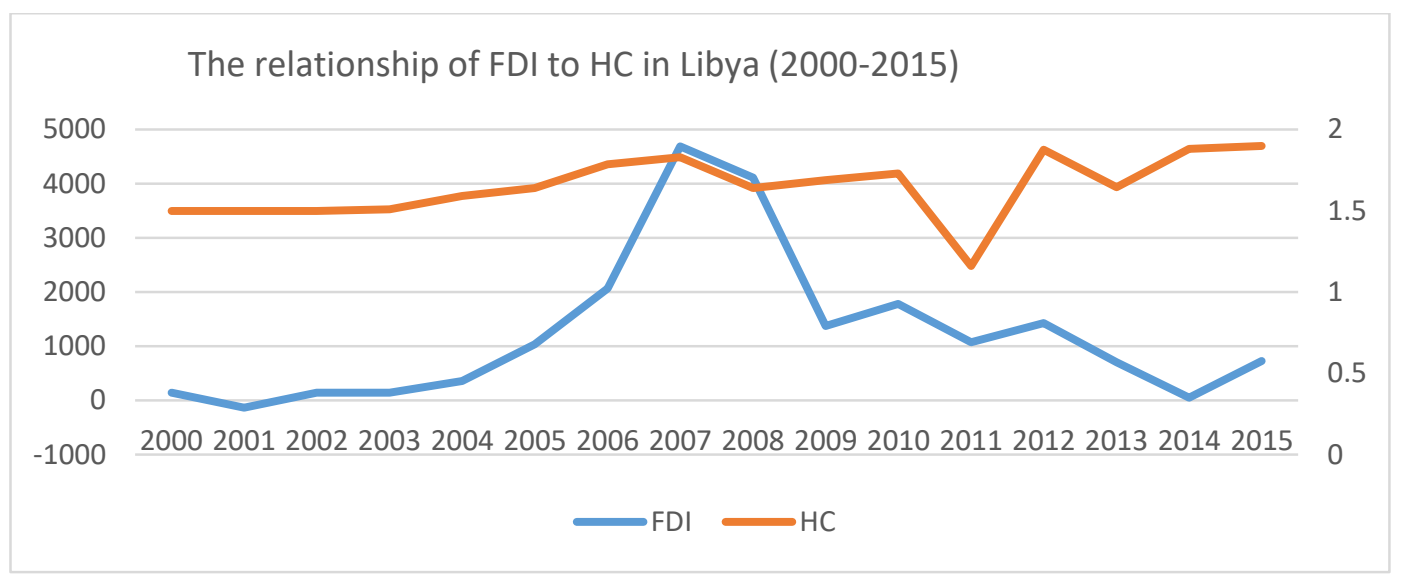

Fig.2: The relationship of foreign direct investment to human capital in Libya during the period (2000-2015)

Source: prepared by researchers, depending on: - UNCTAD, online statistics database.

The above table notes the extent to which the flow of foreign direct investment (FDI) to the labor force in Libya is correlated with the period in which the presence of multinational companies contributed to a significant reduction in unemployment.

In 2000-2015, the flow of foreign direct investment (FDI) is on the rise, but the labor force is relatively high in 2000-2010; this indicates that multinational corporations have not been able to absorb the excess unemployment, Big of the unemployed.

During this specific period, Libya had a high unemployment rate because of its heavy reliance on foreign labor, which made multinationals unable to absorb and employ all the unemployed.

\section{Investment climate in Libya:}

Libya is one of the preferred investment destinations. Libya has a unique and strategic position, which makes it a link between the producing countries and the consumer countries. This motivates the entry of foreign investors to Libya

Natural resources are considered one of the main factors behind the economic growth in Libya, which is one of the most important factors that boosted the foreign investor, so it contains natural resources of high quality. 
Libya's security, political and economic stability between 2000 and 2010 is one of the biggest factors attracting foreign investors. As well as the international agreements held by Libya, whether regional or international, which facilitated the movement of capital between Libya and the rest of the world.

Libya has huge amounts of oil, with oil accounting for the bulk of GDP and total exports. It also has large quantities of natural gas. The presence of these important sources of energy is an important factor to attract foreign investors. In addition to the limited taxes in Libya on consumer goods and capital, which will contribute to the creation of a climate of foreign direct investment.

The development of foreign direct investment in Libya:

Foreign direct investment (FDI) is an important indicator of the increasing interdependence of economies around the world. Where foreign direct investment in its various forms is the artery that sustains the continuity of the life of any economy.

Libya has a lot of different natural resources, suitable geographical location, Libya it is one of the most countries must benefit from foreign direct investment. After Libya gained independence in the early 1950s, it began to build a trade and economic base with the rest of the world, especially Western Europe, which led to economic growth, the spread of education, society and the building of civilized cities. The discovery of oil was a key element to attracting FDI at first. When Libya adopted the socialist system, after the coup in 1969.
Where socialist ideas dominated all economic activities in Libya during the second half of the 1970s and made the door closed to foreign investors and local investors. Libya was involved in many political problems in the 1980s, Libya faced sanctions on political issues, the United States rushed to impose sanctions on Libya in 1982; (despite attempts by business groups, such as oil companies with concessions in Libya to persuade the administration The United Nations Security Council imposed sanctions on Libya in 1992, which led to Libya's situation in acute conditions, resulting in economic contraction in all economic sectors and economic downturn. This adverse economic situation has affected the Libyan economy. These difficult conditions make Libya ask for foreign aid. Moreover, the Libyan authorities are taking steps to attract foreign direct investment and have tried to flow into the country to modernize the economy. Despite the existence of real reforms there is a great reluctance of foreign investors to enter Libya.

The civil war in 2011 reduced oil and gas production in August 2011 by more than 70 per cent. This has led to a significant contraction in GDP, export earnings and tax revenues.

Libya continues to face high levels of security and violence incidents, which have intensified since the second half of 2013 due to increased tensions between regional militia groups.

Development of FDI in Libya during the period (2000-2015)

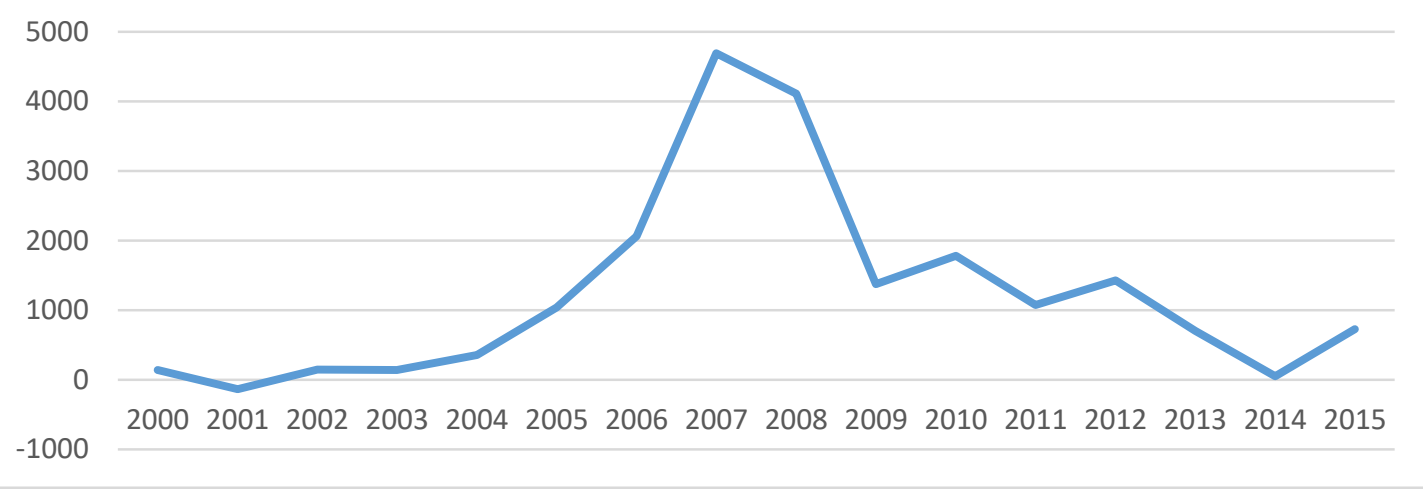

Fig.3: Development of foreign direct investment in Libya during the period (2000-2015)

Source: prepared by researchers, depending on: - UNCTAD, online statistics database.

Measuring the impact of FDI on economic growth in Libya.

Standard Model:

The study aims at measuring the impact of foreign direct investment on economic growth in Libya during the period 2000-2015, assuming that foreign direct investment positively affects Libya's economic growth.
Depending on the multiple regression model, using the normal lower squares method, and the equation can be formulated as follows:

Where:

$$
\begin{aligned}
& \mathrm{Y}=\mathrm{C}+\beta 1 \mathrm{X} 1-\beta 2 \mathrm{X} 2+\beta 3 \mathrm{X} 3+\mathrm{U} \\
& \cdot \mathrm{C}=\text { cutter. } \\
& \cdot \beta 1, \beta 2, \beta 3=\text { form parameters. }
\end{aligned}
$$


-Y = economic growth, measured by the GDP index of $\$$ 1 million at current prices.

-X1 = FDI, measured by net inflows of foreign direct investment (FDI) at $\$ 1$ million at current prices.

-X2 = Labor force (per 1,000 people).

-X3 = inflation rate.

- $\mathrm{U}=$ random variable

\section{Characterization of Form Variables:}

The standard model includes a dependent variable of economic growth, a separate variable, FDI, as well as a second independent variable representing the labor force, while the third independent variable expresses the inflation rate.

\section{Economic Growth:}

Economic growth is the best measure of overall economic performance, as rising economic growth leads to higher national income, thus increasing the welfare of society. Economic growth was measured by the GDP index. Based on the study of Najm \& Al Mazroui, 2012, GDP is one of the most important economic indicators that reflect economic activity in Libya. It represents the total value of goods and services produced from locally existing resources over a period of time Concerned, usually a year. " It is one of the best measures to measure the size of the economy.

\section{direct foreign investment:}

The definition of foreign direct investment (FDI) has been addressed in the first chapter of the United Nations Conference on Trade and Development (UNCTAD), where FDI is one of the policies on which Libya relies to move its economy and diversify its production. (Figure 1) shows that the increase in foreign direct investment in Libya during the period (2000-2015) led to an increase in the gross domestic product (GDP) due to Libya's efforts to provide the necessary investment environment to attract foreign investors.

\section{Labor Force:}

The World Bank, World Development Indicators, Labor Force, defines "all persons representing labor engaged in the production of goods and services within a specified period". The labor force is an important economic human resource in Libya, noting that the labor force is increasing. Libya's political and security stability until the end of 2010, in addition to its economic prosperity, has led to an increase in job opportunities. To increase the labor force. However, based on the study (Hussein \& Ahmed, 2012), the increase in the labor force in Libya, leads to an increase in Expenditure, which negatively affects the GDP.

\section{Inflation rate:}

Thedata World Bank, in World Development Indicators (WDI), showed inflation as "indicative of the rate of price change in the economy as a whole." According to AlMazroui's study (2012), inflation occurs either because of the increase in aggregate demand for goods and services, resulting in higher prices, which is known as inflation caused by demand. Another inflation is due to the high cost of domestic and imported products, such as high oil prices, which result in a rise in the overall price level, which is known as inflation due to increased cost. And that the rate of inflation may indicate the movement of capital and the recovery of the economy.

\section{Data of Study Variables:}

The following table shows the data that reflect the values of variables studied during the period (2000-2015), based on World Bank data, World Development Indicators. UNCTAD, the online statistics base.

Table.1: Time series of study variables during the period (2000-2015).

\begin{tabular}{|c|c|c|c|c|}
\hline Year & GDP (Y) & FDI (X1) & HC (X2) & INF (X3) \\
\hline 2000 & 38.27 & 141 & 1.500 & -2.907 \\
\hline 2001 & 34.11 & -133 & 1.500 & -8.839 \\
\hline 2002 & 20.48 & 145 & 1.510 & -9.863 \\
\hline 2003 & 26.26 & 143 & 1.590 & 1.252 \\
\hline 2004 & 33.12 & 357 & 1.640 & 2.658 \\
\hline 2005 & 47.33 & 1038 & 1.787 & 1.465 \\
\hline 2006 & 54.96 & 2064 & 1.830 & 6.211 \\
\hline 2007 & 67.51 & 4689 & 1.640 & 401610 \\
\hline 2008 & 87.14 & 4111 & 1.688 & 2.448 \\
\hline 2009 & 63.02 & 1371 & 1.729 & 2.458 \\
\hline 2010 & 74.77 & 1784 & 1.160 & $902 ، 15$ \\
\hline 2011 & 34.69 & 1072 & 1.875 & 6.072 \\
\hline 2012 & 81.90 & 1425 & 1.644 & 2.594 \\
\hline 2013 & 65.50 & 702 & 1.880 & 2.8 \\
\hline 2014 & 41.14 & 50 & 1.900 & 9.84 \\
\hline 2015 & 29.15 & 725 & & \\
\hline
\end{tabular}


Source: prepared by researchers, depending on: -

- UNCTAD, Statistics Database Online.

- World Bank, World Development Indicators, Database online

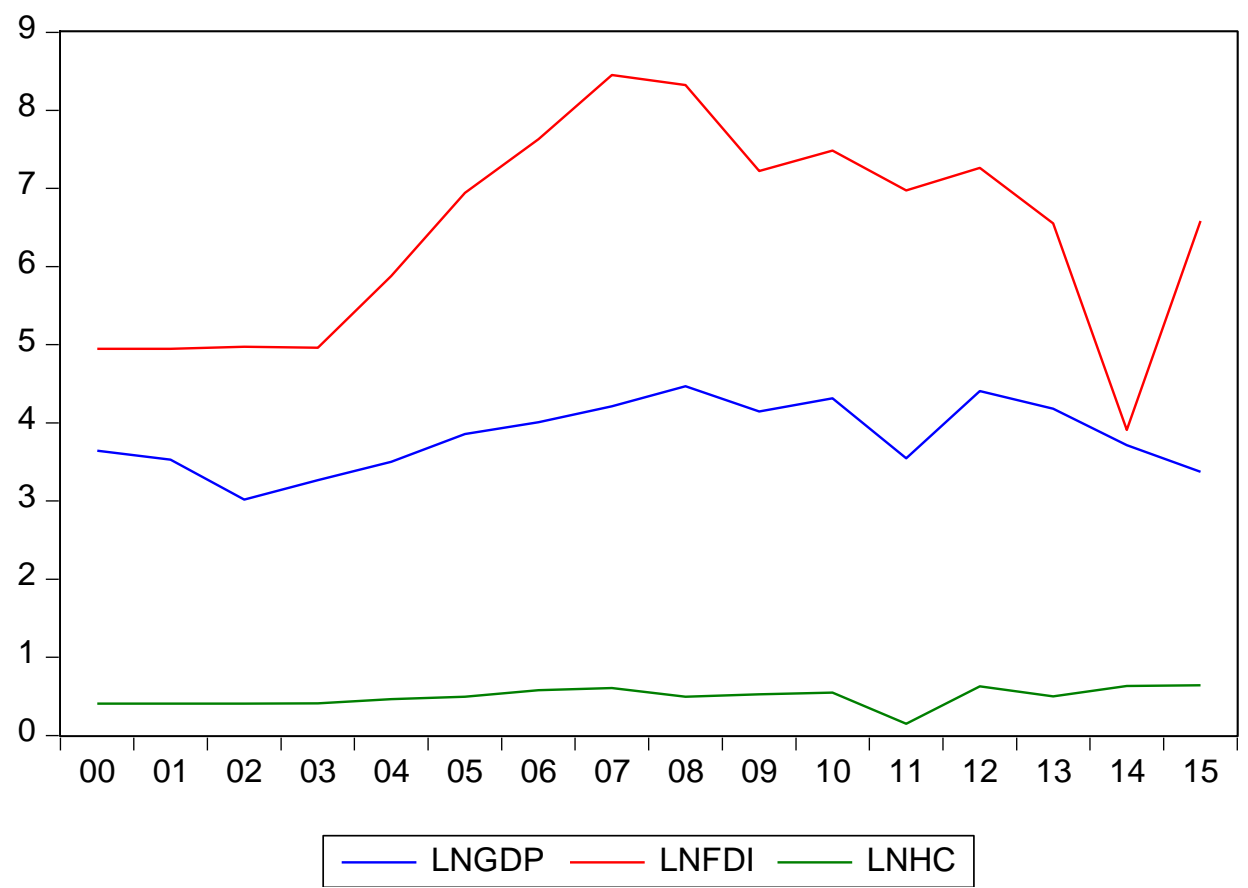

Fig.4: The relationship between $L N G D P, L N F D I$ and $L N H C$

LNGDP

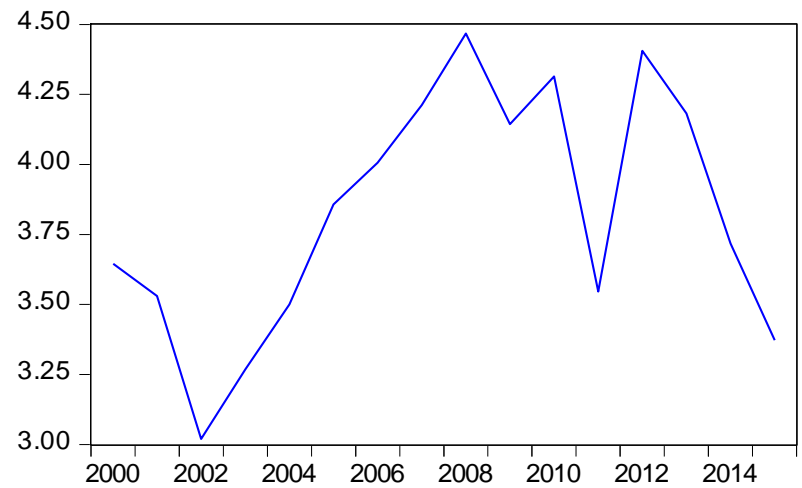

LNFDI

LNHC

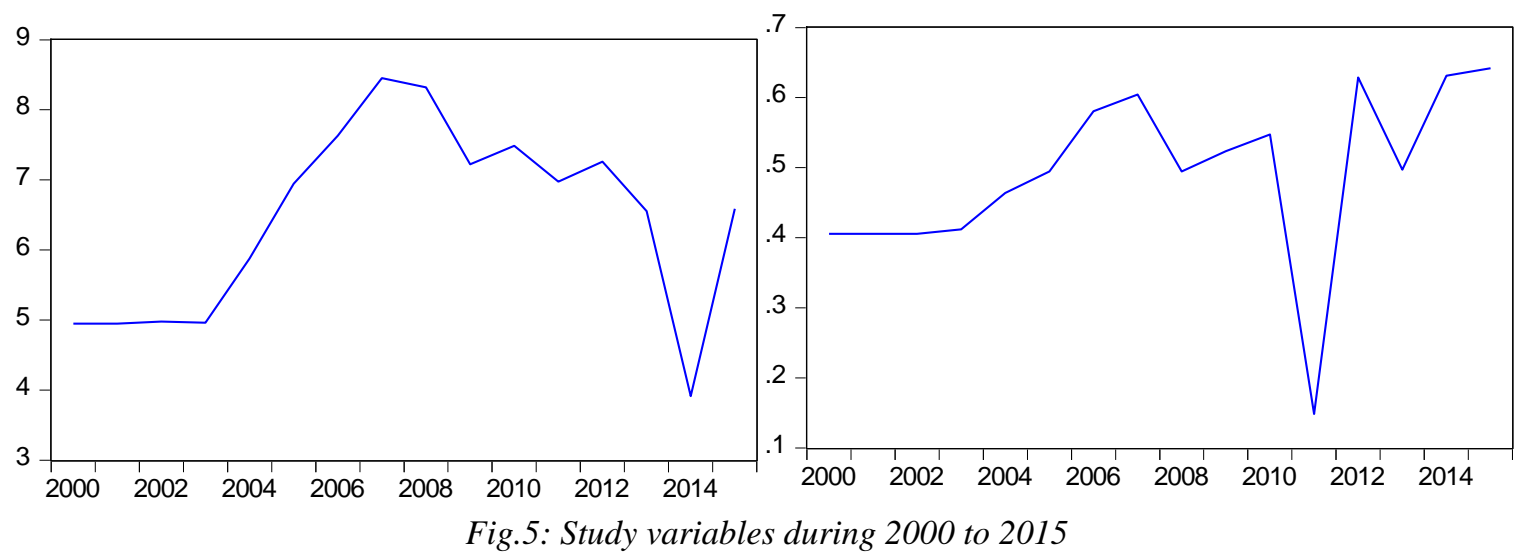

Source: Prepared by the researchers, through the SPSS program), based on the data in Table (1). 
Figure (5) shows the variables of the study. The indicator refers to the dependent variable, which is the economic growth as measured by GDP.

It is noticeable from the previous figure that the GDP is increasing during the period (2000-2010) and the increase in oil exports, but in 2011 there is a clear decline in GDP as a result of the popular revolution in the country and the overthrow of the political system in the country.

Then the GDP started to rise gradually in the year 2012 . But with the political vacuum in the country and the drop in oil exports, there is a clear drop in gross domestic product (GDP), until the deficit in the country's general budget is more than 40 percent.

The indicator (X1) shows the first independent variable, which represents FDI. It is clear from the previous figure that foreign direct investment continued to rise during the period (2000-2010) due to Libya's continuous efforts to provide the suitable investment environment. After that, there is a clear decline in direct foreign investment due to the political vacuum in the country.

The $\mathrm{X} 2$ indicator represents the second independent variable, expressed by the labor force. It is noted that there is a continuous rise in the labor force, as discussed previously, as the presence of multinational companies contributes to creating jobs and thus increasing the labor force.

The X3 indicator shows the third independent variable, which was expressed in the inflation rate. It is clear from the previous figure that inflation rates are clearly fluctuating, as the increase in inflation is due to the large volume of employment in the country, with a decline in GDP and a rise in the prices of goods and services.

Standard model estimation results

Table.2: Descriptive Statistics

\begin{tabular}{|l|c|c|c|}
\hline & Mean & Std. Deviation & $\mathrm{N}$ \\
\hline $\operatorname{lnGDP}$ & 3.8242 & .43823 & 16 \\
\hline $\operatorname{lnFDI}$ & 6.4418 & 1.35278 & 16 \\
\hline $\ln \mathrm{HC}$ & .4928 & .12457 & 16 \\
\hline
\end{tabular}

According to Table 2, descriptive statistics were extracted from 16 observations representing 16 years, as the descriptive statistics for each year differ from each other.For example, it can be noted in Table 2 that the means and standard deviations of economic growth value are 3.8242 and 0.43823 , followed by foreign investment 6.448 and 1.35278 , followed by the value of human capital (labor force, 0.4928 and 0.12457 , respectively.

Table.3: Residuals Statistics ${ }^{a}$

\begin{tabular}{|l|c|c|c|c|c|}
\hline & Minimum & Maximum & Mean & Std. Deviation & $\mathrm{N}$ \\
\hline Predicted Value & 3.4129 & 4.3717 & 3.8242 & .34214 & 16 \\
\hline Residual & -.63752 & .32932 & .00000 & .27384 & 16 \\
\hline Std. Predicted Value & -1.202 & 1.600 & .000 & 1.000 & 16 \\
\hline Std. Residual & -2.167 & 1.120 & .000 & .931 & 16 \\
\hline
\end{tabular}

a. Dependent Variable: lnGDP

Table.4: Results of model estimation

\begin{tabular}{|c|c|c|c|c|c|c|}
\hline \multirow{2}{*}{\multicolumn{2}{|c|}{ Model }} & \multicolumn{2}{|c|}{ Unstandardized Coefficients } & \multirow{2}{*}{\begin{tabular}{|c|}
$\begin{array}{l}\text { Standardized } \\
\text { Coefficients }\end{array}$ \\
Beta \\
\end{tabular}} & \multirow[b]{2}{*}{$\mathrm{t}$} & \multirow[b]{2}{*}{ Sig. } \\
\hline & & $\mathrm{B}$ & Std. Error & & & \\
\hline \multirow[t]{3}{*}{1} & (Constant) & 1.929 & .434 & & 4.443 & .001 \\
\hline & $\operatorname{lnFDI}$ & .215 & .057 & .663 & 3.736 & .002 \\
\hline & $\ln \mathrm{HC}$ & 1.039 & .624 & .295 & 1.665 & .120 \\
\hline
\end{tabular}

Table.5: Model Summary ${ }^{b}$

\begin{tabular}{|c|c|c|c|c|c|c|c|c|c|c|}
\hline \multirow[b]{2}{*}{ Model } & \multirow[b]{2}{*}{ K } & \multirow[b]{2}{*}{$\mathrm{R}^{2}$} & \multirow{2}{*}{$\begin{array}{c}\text { Adjusted } \\
\mathrm{R}^{2}\end{array}$} & \multirow{2}{*}{$\begin{array}{l}\text { Std. Error of } \\
\text { the Estimate }\end{array}$} & \multicolumn{5}{|c|}{ Change Statistics } & \multirow{2}{*}{$\begin{array}{l}\text { Durbin- } \\
\text { Watson }\end{array}$} \\
\hline & & & & & $\mathrm{R}^{2}$ Change & F Change & df1 & df2 & Sig. F Change & \\
\hline 1 & $.781^{\mathrm{a}}$ & 610 & .549 & .29415 & .610 & 10.147 & 2 & 13 & .002 & 1.383 \\
\hline
\end{tabular}

a. Predictors: (Constant), $\ln \mathrm{HC}, \ln \mathrm{FDI}$

b. Dependent Variable: lnGDP 


\section{MODEL SUMMARY}

The first step in evaluating the regression model is using squared R. When the value of R-scard is very close to 1.00 , we can conclude that the significant effects of independent variables.This means that the $\mathrm{R}$ squared value reflects the total variance ratio in the dependent variable, as this variance is due to the regression prediction of the independent variables (Woodhouse, 2003).

Thus, from Table 5 , it can be concluded that the $\mathrm{R}$ squared value indicates that about $61 \%$ of the changes in the economic growth rate can be attributed to foreign direct investmentIn addition, Table 5 shows that multiple $\mathrm{R}$ values represent the multiple correlation of 0.781 (column "R"), indicating a high degree of correlation between all forecasters in the model (FDI, human capital value (labor force), And the value of inflation was excluded due to the absence of reliable data (and the dependent variable) which is economic growth. And Durbin-Watson $d=1.383$, where this value between the two forest values is $0.562<\mathrm{d}<2.220(\alpha=0.05)$ (Anderson, Sweeney, Williams, Cam, \& Cochran, 2014). Thus, it can be assumed that there is no automatic correlation in the current multiple linear regression data.As shown in the above table, the estimated value of the parameters was as follows: The independent variable (ln FDI) coefficient (0.215) was positive. This means that the increase in FDI by $1 \%$ leads to an increase in GDP by $0.215 \%$ The estimated general line has given the best results, as follows: $\mathrm{LnGDP}=1.929+0.215 \ln \mathrm{FDI}+$ $1.0391 \mathrm{nHC}$ and this satisfies the assumption that increased foreign direct investment leads to the higher economic growth rate in Libya.

\section{RESULTS}

After analyzing the data using several techniques for statistical analysis or disclosing the relationship between the independent variables (foreign investment, labor force, Inflation rate in the Libyan economy) and the dependent variable (the rate of growth in the Libyan economy) for 16 years during the period 2000-2015, the researcher reached the following conclusions(:Acceptance of the main premise on which the study was based) (The increase in foreign direct investment leads to a high rate of economic growth in Libya).In the light of data analysis, a quantitative approach was used using the self-regression analysis followed by causation Werner Granger and pulse response (IRF). The results of the normative analysis of the relationship between the economic growth rate in Libya and some independent variables (foreign investment, labor force, inflation rate in the Libyan economy) showed that the value of the fourth quarter indicates that the value of Quadrature $\mathrm{R}$ indicates that about $61 \%$ Changes in the rate of economic growth can be attributed to FDI and human capital (labor force), indicating a good suitability for the regression model of this study.

In addition, the multiple $\mathrm{R}$ values represent the multiple correlation of 0.781 (column "R"), indicating a high degree of correlation among all forecasters in the model (FDI, human capital value (labor force), value excluded Inflation is due to the absence of reliable data (and dependent variable), economic growth, and Durbin Watson $=1.383$, where this value is between the two values of forest $0.562<\mathrm{d}<2.220(\alpha=0.05)$ (Anderson, Sweeney, Williams, Kam \& Cochran, 2014 ), So it can be assumed that there is no automatic correlation in the current multiple linear regression data.

The coefficient of the independent variable $(0.215)$ was positive, which means that the $1 \%$ increase in foreign direct investment leads to an increase in GDP by $0.215 \%$ (economic growth rate). The estimated general line gave the best results, Direct economic growth in Libya.

\section{REFERENCES}

[1] Hamoudi, M. K. T. E. (2016). Libyan Environment to Attract Foreign Direct Investment Libya 20002015. Imperial Journal of Interdisciplinary Research, 2(12).

[2] Almnfi, M., \& Yang, L. (2015). Foreign Direct Investment within the Country of Libya as PostConflict Region: The Image of Oil Industry after (2011). International Journal of Learning and Development, 5(2), 1-6.

[3] Abushhewa, A., \& Zarook, T. (2016). The Effects of Foreign Direct Investment on Economic Growth in Libya: A Causality Analysis. Open Science Journal, 1(2).

[4] Hamoudi, M. K. T. E. (2017). Assess the Foreign Investment Climate in Libya 2000-2015. International Journal of Management and Commerce Innovations ISSN 2348-7585 (Online).

[5] Bandar Bin Salem Al Zahrani, Foreign Direct Investment and its Role in Economic Growth in the Kingdom of Saudi Arabia, 1970-2000, Master Thesis.

[6] Demirhan, E., \& Masca, M. (2008). Determinants of foreign direct investment flows to developing countries: a cross-sectional analysis. Prague economic papers, 4(4), 356-369.

[7] Hamoudi, M. K. T. E. (2017). The Role Of Foreign Investment In Economic And Social development in libya. international journal of scientific \& technology research volume 6 , issue 02 , february 2017 issn 2277-8616. 
[8] Efhialelbum, A., \& Flatau, P. (2013). Did Foreign Direct Investment contribute to the Libyan Economic Growth in Transition Period?. Mediterranean Journal of Social Sciences, 4(9), 46.

[9] Sârbu, M. R. (2014). Forms And Motivations Of Foreign Direct Investment. SEA-Practical Application of Science, (3), 532-540.
[10] Hamoudi, M. K. T. E. (2016). The Impact of Fiscal Policy on Investment in Libya. Library Journal, 3, e3184.

[11] https://www.indexmundi.com/libya/inflation_rate (c onsumer_prices).html 